\title{
MANUFACTURING AND CONTINUOUS IMPROVEMENT PERFORMANCE LEVEL IN PLANTS OF MEXICO; A COMPARATIVE ANALYSIS AMONG LARGE AND MEDIUM SIZE PLANTS
}

Carlos Monge', Jesús Cruz"

Universidad Autónoma de Nuevo León, Monterrey, México

\section{ABSTRACT}

A random and statistically significant sample of 40 medium (12) and large (28) manufacturing plants of Apodaca, Mexico were surveyed using a structured and validated questionnaire to investigate the level of implementation of lean manufacturing, sustainable manufacturing, continuous improvement and operational efficiency and environmental responsibility in them, it is important to mention it was found that performance in the mentioned philosophies, on the two categories of plants is low, however large plants show a better performance than medium plants. In both cases, it is worrying that in the highly industrialized municipality of Apodaca, Mexico are not decisively adopting the philosophies mentioned, as this compromises in a global world, in the medium and long term the viability of the plants, particularly the medium size plants. Finally this article shows the results of the answers to the items of questionnaire for the plants managers, and this can be useful to the management of the plants to identify and to define specific improvement actions towards priority areas.

\section{JEL CLASSIFICATION \& KEYWORDS}

- C12 C18 - C39 - LEAN MANUFACTURING - SUSTAINABLE MANUFACTURING CONTINUOUS IMPROVEMENT OPERATIONAL EFFECTIVENESS AND ENVIRONMENTAL RESPONSIBILITY

\section{INTRODUCTION}

The benefits of lean manufacturing or simply named lean are evident nowadays in manufacturing plants around the world, says Ferdousi et al., (2009), so advanced and developing countries are implementing this philosophy in order to achieve significant improvements in operational efficiency and competitive advantage in a global world. Cooper et al., (2008) and Monge et al., (2013, 2014a, 2014b) refer that lean has outstanding effects on operational efficiency (improved quality, lower costs, reduced lead times, on-time delivery, reduction cycle times and improved customer service), but not always their financial effects are seen in the short term (Cooper et al., 2008).

The concept of lean manufacturing or "lean", was introduced in 1990 in the western world with the publication of the book "The machine that changed the world" by Dr. James P. Womack based in the five-year study conducted by MIT in automobile manufacturing plants worldwide mainly in Japan, within its International Motor Vehicle Program (IMVP). The book showed how management, operators and suppliers could work together to improve quality, productivity and reduce costs. Lean manufacturing can help achieve improvements in: lead times of 1 week, on-time deliveries of $90 \%$, reduced inventory by $80 \%$, increase in capacity between $36-48 \%$ (Cooper et al., 2008), obtaining substantial improvements in operational efficiency through: Enhancements of quality, on-time delivery, cost reductions,

\footnotetext{
' carlosmongep@prodigy.net.mx

" jesusphd@prodigy.net.mx
}

www.journals.cz delivery speed, cycle times, increased employee productivity and improved plant capacity, without increasing headcount and achieving a positive impact on financial results (Cooper et al., 2008), Monge et al., (2014a).

Similar results can be obtained in other contexts knowledge intensive, as the field of health care with the implementation of lean culture (Toussaint et al., 2013), the lean approach requires new habits and new skills, lean concept is not a destination but a journey, which involves an insatiable quest for improvement, so lean philosophy and lean manufacturing are closely linked to continuous improvement and, both with improved operating performance (Toussaint et al., 2013; Monge et al., 2014a, 2014b; Murugesan et al., 2012; Vinohd et al., 2012; Koenigsaecker, 2009; Cooper et al., 2008), while Murugesan et al., (2012) and Vinohd et al., (2012) indicate that achieving greater operational efficiency obtained through lean manufacturing has a significant, positive and direct impact on the competitive advantages of the business including: quality at first intention, reduced delivery times and productivity gains (Ghosh, 2013; Monge et al., 2014a, 2014b).

Regarding sustainable manufacturing (Jiang et al., 2012; Millar et al., 2011) and recent studies (MIT and BCG, (2013, 2011, 2009), Monge et al., (2014a, 2014b, 2013) and Bergmiller et al., (2011) as well as Millar et al., (2011), Murugesan et al., (2012), Wills (2009a, 2009b) and (EPA, 2000) show that sustainable manufacturing can help organizations to achieve better operating performance and an improved environmental performance simultaneously supporting with this the sustainability efforts of the plants and, impacting directly and positively the: financial results, carbon footprint, organizations sustainability culture and the employees satisfaction.

The topic is very important considering that global manufacturing consumes large amounts of resources and generates huge amounts of waste, suffice it to say that manufacturing worldwide consume a third of the world's energy and generates $36 \%$ of total CO2 (Millar et al., 2011) the main greenhouse gas (GHG), the emissions in Mexico Irastorza et al., (2010) indicate that the power generating industry contributes with $21 \%$ and manufacturing by $8 \%$ to emission of that gas, however it is the industry that consumes more energy accounting $60 \%$, while only $30 \%$ of companies in Mexico have a system of energy measurement, which shows the low environmental awareness of companies (Rodríguez, 2011), is therefore essential that the manufacturing plants adopt sustainable practices (Bergmiller et al., 2011) or sustainable manufacturing.

In this sense there is evidence that sustainability and sustainable manufacturing are becoming increasingly important worldwide as revealed by the studies of: Schneider Study, (2011) and MIT and BCG, (2013, 2011, 2009), which show trends in recent years towards a change in the attitude of senior executives of the organizations, the 
executives have changed from considering that the issue of sustainability and its adoption, are important only if they bring short-term economic benefits, to consider the sustainability an important differentiation factor (Millar et al., 2011) for achieving strategic and competitive advantages via innovation of products and processes, which provide access to new markets, an improved image of the organization in the society, brand reputation and increase the shareholder value. In the case of Mexico a similar study was conducted by the consulting firm KPMG (KPMG, 2009) and the results are alike to studies by MIT and BCG already mentioned.

In relation to continuous improvement, Murugesan et al., (2012), Koenigsaecker, (2009) and Imai, (1986) reported that continuous improvement (kaizen), another of the issues addressed in this study, is a key ingredient for competitive advantage, survival and growth of organizations, however the literature reveals that lean manufacturing and continuous improvement have not been well understood in the western countries, and as a result it is considered that its implementation is only the adoption of isolated tools and lean techniques, and not as a whole process of continuous improvement, thus generating "lean silos" and not a comprehensive implementation that would bring great benefits and competitive advantages. According to Bergmiller et al., (2011) and Liker et al., (2011) this is mainly due to the lack of commitment and leadership of senior management, as well as inadequate employees training in western plants.

In the context of manufacturing and particularly in plants of Mexico, the adoption of continuous improvement, lean manufacturing and sustainable manufacturing are not strongly implemented as shown in this article based heavily on previous research by Monge et al., (2014a, 2014b, 2013), these initiatives are not reflected in continuous improvement actions, as is confirmed in the study of Reyes-Aguilar, (2002), which shows a low participation of Mexican plants in these approaches either individual through individual proposals for improvement or group, so it must be said that the efforts are isolated initiatives and not systematically performed.

Now, although it is frequently mentioned in the literature the positive effects that lean manufacturing, sustainable manufacturing and continuous improvement have in operating performance, environmental responsibility and financial results, there are few empirical studies in Mexico using descriptive statistics or multivariate analysis showing the level of adoption in Mexican plants of the philosophies mentioned, among the studies reviewed are those of: Monge et al., (2014a, 2014b, 2013), Reyes Aguilar, (2002). In the context of the Caribbean by Millar et al., (2011) and India of Ferdoussi et al., (2009), Murugesan et al., (2012). Finally the descriptive statistics results obtained in this study can be used as guides for the manufacturing plants located in Apodaca, Mexico to guide actions to improve operational efficiency and environmental responsibility in combination, in order to impact the triple bottom line, profit-societyenvironment (Slaper, 2011).

\section{Literature reviewing}

For the realization of this article a review of the literature was conducted related to the topic of study in order to know the contributions that have been made about it, those theoretical elements founds were extracted from various recognized literature sources as indexed journals, books and digital databases including: Scielo Mexico, Scielo Chile, Chile Informacion Tecnologica, databases of the National
Autonomous University of Mexico, Academic One file, Host EBSCO Academic Search Complete, EBSCO Business Source Complete, EBSCO Econlit with Full Text, Springer and Elsevier.

\section{Lean manufacturing}

Monge et al., (2014a, 2014b, 2013) in a study conducted in a statiscally representative sample of 40 large and medium size manufacturing plants of Apodaca, Mexico, showed using Structural Equation Modeling PLS SEM and a reflective scale that Lean Manufacturing Effectiveness (LME), Sustainable Manufacturing Effectiveness (SME) and Continuous Improvement Effectiveness (CIE) have a positive effect, direct and statistically significant impact in Operational Efficiency and Environmental Responsibility Index (OE\&ERI) influencing positively the Financial Results (FR), Carbon Footprint Impact (CFI), Employee Satisfaction (ES) and the creation of Culture of Sustainability in the Organizations (CSO) the model is shown in Figure 1, the study however did not show the performance of the plants in Apodaca, Mexico in the different aspects that constitute the lean manufacturing, sustainable manufacturing and continuous improvement approaches, nor indicated what category medium or large plants are performing better. Cruz et al., (2015) propose in their paper a theoretical model for Manufacturing Excellence and its Impact on Business Performance and it is important to mention that the model includes the Lean Manufacturing like a key component.

Murugesan et al., (2012) presents a study that considers a multiple regression model to correlate two independent variables, the world class manufacturing (WCM) and Lean Manufacturing (LM) with the dependent variable Competitive Advantage or Operational Performance (OP), all of these variables are multidimensional, empirical data were collected from 125 manufacturing plants in southern India and the result showed that both World Class Manufacturing (WCM) and Lean Manufacturing are closely linked to Operational Performance and Competitive Advantage. It is noteworthy that Upadhye et al., (2010) believe that the world class manufacturing (WCM) and lean manufacturing are the same.

Lee, (2012) in a study of 970 manufacturing companies in 18 countries, applied modeling with Structural Equations to empirically test the relationship between Lean Manufacturing and Total Quality management (TQM) in Operational Performance (operational efficiency), the results revealed that the two aspects have a positive impact, direct and statistically significant in the Operational Performance measured by dimensions: quality, cost, speed and flexibility, in some other studies these dimensions are expanded to include some other measurements (Murugesan et al., 2012).

Ferdousi et al., (2009) in a study conducted in 8 garments industry firms from Bangladesh, showed using a semistructured questionnaire these companies were getting significant benefits by adopting lean manufacturing techniques, however the study also records that the degree of adoption of lean manufacturing practices were not high in those firms. Amin et al., (2013) developed a mathematical model of optimization in order to help manufacturing plants to select the proper lean Manufacturing strategies to eliminate or reduce waste given the constraints of resources of the plants and thus improve operational performance, the model quantitatively evaluates the perceived value of lean strategies in reducing waste through an optimal solution built with MATLAB, the results show that the perceived value of the waste reduction can change significantly according 
to the policies and product strategies considered by the manufacturer.

Austin et al., (2013) states that given the changing customer needs and current technological requirements, organizations are forced to implement initiatives "lean" in its production processes in order to ensure better operational performance (operational efficiency) and competitive advantage, the study presents in the automotive context birthplace of "lean" concept, a model developed using the technique of Hierarchical Analysis Process (AHP), in its implementation a questionnaire was applied to 15 Indian auto companies, the model relates "lean" practices and techniques with competitive objectives and identifies which of the various "lean" tools have greater impact in achieving a "lean" performance.

Ghosh, (2013) study shows the current situation in the implementation of lean practices in manufacturing plants in India and their impact on operational performance, the study was conducted using a questionnaire applied to 79 plants in different regions of India, and as lean manufacturing is a multidimensional construct was found that $80 \%$ of the plants has implemented various dimensions of lean manufacturing such as: focus on customer needs, pulled production systems, reduced mold exchange time (SMED), total Productive Maintenance (TPM), relationship with suppliers, statistical process control and problem solving process. It was also found that productivity has increased, the quality at first intention has improved, reduced delivery times and inventories as well as the occupied space, to summarize, respondents said that the quality at the first time, time delivery reduction and increased productivity are the three main drivers of the adoption of lean manufacturing in that context.

In the Latin American context there have been some studies in relation to the adoption of lean manufacturing, Cardozo et al., (2011) analyzed the production process of 45 smal and medium enterprises producing cheese in Venezuela, to determine the adoption of the dimensions of lean manufacturing in particular $5 \mathrm{~S}$ and the adoption of sustainable practices (sustainable manufacturing) in these organizations, the results showed that companies have limitations on the adoption of both approaches, limiting their competitiveness. Arrieta et al., (2012) in their study also show very low diffusion of lean initiatives in the garment sector in non-foreign companies in Colombia. Mexico case is not very different according to the study of Reyes-Aguilar, (2002) and Monge et al., (2014a, 2014b, 2013).

Vinodh et al., (2012), Monge et al., (2014a, 2014b, 2013) describe that often the plants consider lean manufacturing improves the competitiveness of business, however, there is little evidence in the literature about empirical studies validating the positive impact on organizational performance, and showing the level of adoption of the lean tools and techniques in the plants. In the present article the authors have used the answers of the respondents to the questionnaire proposed for Monge et al., (2013) to do an exploratory and descriptive analysis of lean practices, sustainable manufacturing practices, and continuous improvement initiatives adoption in Apodaca Mexico manufacturing plants, in order to guide the managers of the plants to define proper improvements actions plans.

Sustainable manufacturing

Sustainable manufacturing (Jiang et al., 2012; Millar et al., 2011) based on principles of sustainability and sustainable development, unlike lean manufacturing that pursue waste elimination in a continuous improvement process, seeks to eliminate environmental wastes in production processes, according to Wills, (2009a, 2009b) are: energy - especially electricity, water, air emissions, water emissions, irrational use of materials, solid or/and hazardous waste, transportation and damage to biodiversity, improving operational performance and competitive advantage. Bergmiller et al., (2011) in another study reports that manufacturing plants successful in lean manufacturing implementation, should also be successful implementing sustainable principles and sustainable manufacturing, Bergmiller's study developed within manufacturing plants finalist of the Shingo Prize, explores the synergy between lean manufacturing and sustainability, establishing in this way the relationship between lean manufacturing and sustainable manufacturing. In Latin America context, Cardozo et al., (2011) in a recent study conducted in 45 plants producing cheese at Venezuela reports that lean manufacturing and sustainable manufacturing are tightly linked and the lack of adoption of these approaches take the enterprises to loss of competitive position.

In the context of the Caribbean, Millar et al., (2011) developed a descriptive study to determine the level of adoption of sustainable manufacturing in the countries of that region and found that Caribbean plants have a limited knowledge of sustainable manufacturing and implementation of these initiatives is scarce. In Mexico the situation is similar in the adoption of sustainable manufacturing by the companies, this may be due to the low culture of sustainability in the manufacturing industry, which prevents them from seeing that environmental commitment supports the achievement of economic benefits (Kidwell, 2006) and simultaneously improves the ecological footprint (Slaper, 2011), neither are able to identify in the combination of lean manufacturing, sustainable manufacturing and continuous improvement, the opportunity to get strategic and competitive benefits like the creation of a culture of sustainability and to improve quality, delivery times, public image, generate greater value for shareholders and employee satisfaction (MIT and BCG, 2013, 2011, 2009; KPMG, 2009).

\section{Continuous improvement}

Continuous improvement - kaizen - (Imai, 1986), applied to manufacturing, is essentially a philosophy that involves the total employees of the companies either individually or in groups, the first through suggestions for improvements and the second via small groups, quality circles or six-sigma projects. The supreme intention is to have all staff of an organization, from senior management to production line workers engaged in an endless pursuit of higher levels of performance in terms of: quality, costs, delivery times, flexibility, security and moral employees (Koenigsaecker, 2009), the primary feature is that improvement efforts may be small (Kaizen), dramatic (Innovation) or a combination of both, as long as such efforts are continuous (Imai, 1986), and is determinant for the success of the continuous improvement initiative to count with active and motivated employee participation.

As for continuous improvement, the studies cited in sections of lean manufacturing and sustainable manufacturing demand continuous improvement actions (Austin et al., 2013; Ghosh 2013; Jiang et al., 2012; Lee et al., 2012; Murugesan et al., 2012; Cardozo et al., 2011; Wills, 2009a; EPA, 2000), this is consistent because both initiatives lean manufacturing and sustainable manufacturing are approaches of continuous application and not unique events (Bergmiller et al., 2011). Moreover it has already been discussed in previous sections the impact of lean and 
sustainable initiatives in the operational performance or operational efficiency, in fact lean manufacturing and sustainable are often considered philosophies of continuous improvement (Murugesan et al., 2013.; Toussaint et al., 2013;. Bergmiller et al, 2011; Cardozo et al., 2011).

In the literature reviewing process, gaps in knowledge of the theoretical elements studied were also identified, and found that there are few recent studies particularly in Mexico that show the degree of adoption of the techniques and tools like lean manufacturing, sustainable manufacturing and continuous improvement, and the level of impact that has this level of adoption in operational efficiency and environmental responsibility of manufacturing plants in Mexico.

Operational efficiency and environmental responsibility (OE \& ERI) model operationalization and variables

The graphical representation of the operationalization of the model discussed in this article is presented in Figure 1. In the model showed was used a scale of reflective measurement including 38 items, integrated in a questionnaire applied to key people in Apodaca Mexico manufacturing plants. Items requested responses on Likert scale or hard data, the results of the responses to items will be shown in the results section.

\section{Methodology}

This article presents an exploratory and descriptive study of the degree of adoption of lean manufacturing practices (LME), sustainable manufacturing (SME) and continuous improvement (CIE) as well as the impact on operational efficiency and environmental responsibility (OE \& ERI) in large (28) and medium size (12) manufacturing plants of Apodaca, Mexico. For this study, the raw scores of the responses of plant managers and/or operations manager in a sample of $40(n=40)$ were used, the responses were obtained through a structured questionnaire with 38 items developed in Monge et al., (2013) study and presented in Tables 1, 2, 3 and 4 in this article, the involved variables are depicted in OE \& ERI graphical model in Figure 1.

The questionnaire was applied face-to-face or by email during the 2013 year, the validity and reliability of the questionnaire and the statistical representativeness of the sample of 40 plants were determined in the study of Monge et al., (2013), who used this sample, and responses to the questionnaire already referred and, used the technique of structural equations PLS SEM for statistical modeling to assess the model of the figure 1.

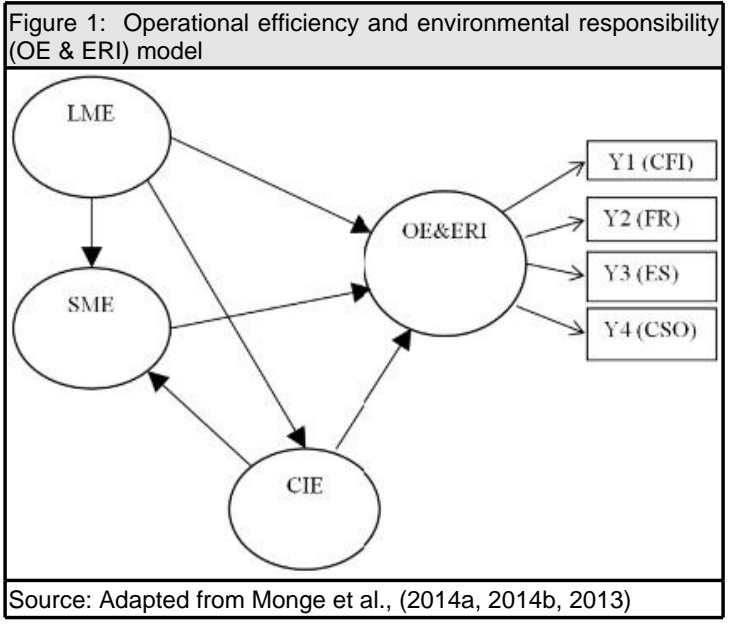

www.journals.cz
Since the questionnaire includes items that requested responses in rate scales either percentages or hard data, interval scale (Likert), will be presented in the results section the average percentages of the responses to the different items for each category of plant -medium and large. For items in Likert scale, were used the average of each items with scores 4 or 5 for the two categories of plants, the reason was to determine and show the items with outstanding or excellent performance indicating a high level of adoption, it is because essentially the idea of the study is to show if the manufacturing plants in Apodaca, Mexico are adopting lean manufacturing, sustainable manufacturing and continuous improvement in a great extent, consistently and in a committed way.

\section{Results}

\section{Lean manufacturing aspects}

In Table 1, you can see the levels of adoption of the different key elements that constitute lean manufacturing philosophy (LME), both in the case of large plants (28) and medium plants (12). It can be seen in Table 1, large companies have a slightly better performance in relation to medium plants in the different elements of lean manufacturing analyzed, however it is important to note that both categories of plants have a level of adoption relatively low for the manufacturing plants in Apodaca, Mexico a worrying fact.

It is interesting to see the results that Apodaca manufacturing plants are no succeeding in the lean manufacturing implementation, and the reasons were warned by Liker et al., (2011) and are lack of commitment and leadership of top management and poor employee training, this situation is common in western manufacturing companies. This circumstance essentially causes "lean" tools be only implemented in an isolated manner, creating "lean silos" and not like a consistent and robust implementation of lean philosophy (Liker et al, 2011; Spear and Bowen, 1999).

\begin{tabular}{|l|l|l|l|}
\hline \multicolumn{3}{|c|}{ Table 1: Items related with Lean Manufacturing Adoption (LME) } \\
\hline No. & Questionnaire item & $\begin{array}{l}\text { Medium } \\
\text { size (12) }\end{array}$ & $\begin{array}{l}\text { Large size } \\
(28)\end{array}$ \\
\hline 1 & Process mapping (\% mapped) & 32 & 38 \\
\hline 2 & 5 S (\% implemented) & 71 & 74 \\
\hline 3 & $\begin{array}{l}\text { Visual management and visual controls } \\
\text { (\% implemented) }\end{array}$ & 45 & 62 \\
\hline 4 & Single Minute Exchange of Die (\% advance) & 18 & 32 \\
\hline 5 & $\begin{array}{l}\text { First time quality and mistake-proof devices } \\
\text { \% implemented) }\end{array}$ & 36 & 42 \\
\hline 6 & Cycle counting (\% implemented) & 38 & 55 \\
\hline 7 & Multiskill operators (\% advance) & 48 & 55 \\
\hline 8 & $\begin{array}{l}\text { Autonomation -jidoka- and poka-yoke devices } \\
\text { \% advance) }\end{array}$ & 18 & 30 \\
\hline 9 & Leveled mixed scheduling -heijunka (\% advance) & 24 & 33 \\
\hline 10 & $\begin{array}{l}\text { Continuous improvement -Kaizen- employees } \\
\text { involvement (\% involved) }\end{array}$ & 48 & 59 \\
\hline 11 & Flow time reduction (\% advance) & 12 & 14 \\
\hline 12 & Lead time reduction (\% advance) & 10 & 13 \\
\hline Source: Adapted from Monge et al., (2013) & \\
\hline
\end{tabular}

Sustainable manufacturing aspects

In Table 2, we can see that there is no clear advantage of the large plants in relation to medium plants in sustainable manufacturing aspects, and both categories exhibit a poor performance, this may be due to the low culture of sustainability in the manufacturing industry in Mexico, which does not allow them to see that the environmental commitment supports the achievement of economic benefits (Kidwell, 2006) and simultaneously improves the ecological footprint (Slaper, 2011), neither are able to identify in the 
combination of lean manufacturing, sustainable manufacturing and continuous improvement, the opportunity to get competitive and strategic advantages, creating a culture of sustainability and improving the quality, cost, delivery times, public image, generate greater value for shareholders and employee satisfaction, everything at the same time (MIT and BCG, 2013, 2011, 2009; KPMG, 2009.

\begin{tabular}{|c|c|c|c|}
\hline No. & Questionnaire item & $\begin{array}{l}\text { Medium } \\
\text { size (12) }\end{array}$ & $\begin{array}{l}\text { Large } \\
\text { size (28) }\end{array}$ \\
\hline 13 & $\begin{array}{l}\text { There is on site a high level management team to drive } \\
\text { the sustainables initiatives (\% answers yes) }\end{array}$ & 66 & 68 \\
\hline 14 & $\begin{array}{l}\text { Years developing sustainables initiatives (Average of the } \\
\text { years) }\end{array}$ & 1.8 & 2.6 \\
\hline 15 & $\begin{array}{l}\text { The sustainable initiatives have improved the productivity } \\
\text { (\% plants with answers } 4 \text { or } 5 \text { on Likert scale, } 5 \text { - totally) }\end{array}$ & 50 & 39 \\
\hline 16 & Transportation reduction (\% achieved) & 2.6 & 5.1 \\
\hline 17 & Green value stream mapping application (\% implemented) & 2.2 & 2.1 \\
\hline 18 & $\begin{array}{l}\text { There are metrics to evaluate the sustainable performance } \\
\text { (\% plants with } 4 \text { or } 5 \text { on Likert scale, } 5 \text {-totally) }\end{array}$ & 16 & 39 \\
\hline 20 & $\begin{array}{l}\text { Currently your company develop environmentally } \\
\text { innovators products (\% plants with } 4 \text { or } 5 \text { on Likert scale, } \\
5 \text { - totally) }\end{array}$ & 8 & 21 \\
\hline 21 & $\begin{array}{l}\text { The sustainable initiatives of your company surpass the } \\
\text { governmental regulations (\% plants with } 4 \text { or } 5 \text { on Likert } \\
\text { scale, } 5 \text { - totally) }\end{array}$ & 33 & 25 \\
\hline
\end{tabular}

Continuous improvement aspects

It is clear from Table 3, there is no marked difference in performance in terms of continuous improvement among large and medium plants in Apodaca, Mexico. But again as in the lean and sustainable manufacturing, the level of performance or adoption of continuous improvement practices is low, continuous improvement is not present consistently and systematically in the studied medium and large plants, according to the results shown in Table 3.

In this sense is important to mention that because the lack of a systematic approach to continuous improvement that operates in a consistent and systematic way, with the active participation of the employees and the commitment and leadership of senior management (Liker et al., 2011), the plants will not be able to consolidate the lean manufacturing and sustainable manufacturing approaches, losing great benefits that are possible to obtain through a wide employee participation, abundant suggestions submission, high level of suggestions implemented, continuous improvement projects, employee involvement in a great extent and a great daily time of the management dedicated to direct shop floor observation, these are according to Koenigsaecker, (2009) fundamental conditions for the success of an excellent continuous improvement system. The results shown in Table 3 indicate far indicators of an outstanding manufacturing plant performance in the matter of continuous improvement.

\begin{tabular}{|l|l|l|l|}
\hline \multicolumn{3}{|l|}{ Table 3: Items related with Continuous Improvement Adoption (CIE) } \\
\hline No. & Questionnaire item & $\begin{array}{l}\text { Medium } \\
\text { size (12) }\end{array}$ & $\begin{array}{l}\text { Large } \\
\text { size (28) }\end{array}$ \\
\hline 22 & $\begin{array}{l}\text { The management is committed with the continuous } \\
\text { improvement (\% plants with 4 or 5 on Likert scale, 5-totally) }\end{array}$ & 75 & 71 \\
\hline 23 & $\begin{array}{l}\text { The company has an evaluation and following system of } \\
\text { the continuous improvement projects and/or suggestions } \\
\text { (\% plants with 4 or 5 on Likert scale, 5 - totally) }\end{array}$ & 58 & 79 \\
\hline 24 & $\begin{array}{l}\text { The continuous improvement projects are focused to } \\
\text { employees safety (\% plants with 4 or 5 on Likert scale, 5 - } \\
\text { totally) }\end{array}$ & 83 & 54 \\
\hline 25 & $\begin{array}{l}\text { Total of the employees trained in continuous improvement } \\
\text { (\% trained) }\end{array}$ & 51 & 64 \\
\hline 26 & $\begin{array}{l}\text { Total employees involved in continuous improvement } \\
\text { projects (\% involved) }\end{array}$ & 26 & 58 \\
\hline 27 & $\begin{array}{l}\text { Suggestions implemented of the total suggested (\% } \\
\text { implemented) }\end{array}$ & 44 & 41 \\
\hline Source: Adapted from Monge et al., (2013) & \\
\hline
\end{tabular}

www.journals.cz
Operational Efficiency \& Environmental Responsibility aspects

In Table 4, items not related to techniques and/or tools are shown, instead there appear answers to items indicating the achievements in manufacturing plants of Apodaca Mexico as a result of the adoption of lean manufacturing, sustainable manufacturing and continuous improvement elements.

It is clear that the achievements are low in both categories, showing the effect of the failure to adopt such practices as shown in tables 1,2 and 3 , this can be considered normal given the lack of commitment and leadership of the top management of the studied plants towards lean manufacturing, sustainable manufacturing and continuous improvement confirming the warnings of Liker et al., (2011), Koegnisaeker, (2009), Imai (1986)

\begin{tabular}{|c|c|c|c|}
\hline \multicolumn{4}{|c|}{$\begin{array}{l}\text { Table 4: Items related with Operational Efficiency \& Environmenta } \\
\text { Responsibility Index (OE \& ERI) }\end{array}$} \\
\hline No. & Questionnaire item & \multirow{2}{*}{\begin{tabular}{|l}
$\begin{array}{l}\text { Medium } \\
\text { size (12) }\end{array}$ \\
41
\end{tabular}} & \multirow{2}{*}{\begin{tabular}{|l}
$\begin{array}{l}\text { Large } \\
\text { size (28) }\end{array}$ \\
36
\end{tabular}} \\
\hline 28 & $\begin{array}{l}\text { The environment improvement is a motivator to adopt } \\
\text { sustainables initiatives (\% plants with } 4 \text { or } 5 \text { on Likert scale, } \\
5 \text { - totally) }\end{array}$ & & \\
\hline 29 & $\begin{array}{l}\text { The company public image improvement is a motivator to } \\
\text { adopt sustainables initiatives (\% plants with } 4 \text { or } 5 \text { on Likert } \\
\text { scale, } 5 \text { - totally) }\end{array}$ & 33 & 50 \\
\hline 30 & $\begin{array}{l}\text { A corporate policy adoption is a motivator to adopt sustainable } \\
\text { initiatives (\% plants with } 4 \text { or } 5 \text { on Likert scale, } 5 \text { - totally) }\end{array}$ & 75 & 50 \\
\hline 31 & $\begin{array}{l}\text { A moral responsibility fulfillment is a motivator to adopt } \\
\text { sustainables initiatives (\% plants with } 4 \text { or } 5 \text { on Likert scale, } \\
5 \text { - totally) }\end{array}$ & 33 & 39 \\
\hline 32 & $\begin{array}{l}\text { Competitives and strategics advantages achievements is a } \\
\text { motivator to adopt sustainables initiatives (\% plants with } 4 \text { or } \\
5 \text { on Likert scale, } 5 \text { - totally) }\end{array}$ & 58 & 43 \\
\hline 33 & $\begin{array}{l}\text { The sustainable and operational performance indicator are } \\
\text { tightly related (\% plants with } 4 \text { or } 5 \text { on Likert scale, } 5 \text { - totally) }\end{array}$ & 25 & 43 \\
\hline 34 & CO2 emissions reduction (\% reduction) & 2.3 & 6 \\
\hline 35 & $\begin{array}{l}\text { The company support the environment care (\% plants with } 4 \\
\text { or } 5 \text { on Likert scale, } 5 \text { - totally) }\end{array}$ & 25 & 29 \\
\hline 36 & $\begin{array}{l}\text { Economic benefit achieved because the adoption of } \\
\text { sustainable initiatives (\% plants with } 4 \text { or } 5 \text { on Likert scale, } 5 \\
\text { - totally) }\end{array}$ & 8 & 1 \\
\hline 37 & $\begin{array}{l}\text { The company develop sustainables projects to the employees } \\
\text { safety improvement (\% plants with } 4 \text { or } 5 \text { on Likert scale, } 5 \text { - } \\
\text { totally) }\end{array}$ & 33 & 29 \\
\hline 38 & $\begin{array}{l}\text { The developing of sustainables initiatives influence your } \\
\text { desire to remain working in the company (\% plants with } 4 \text { or } \\
5 \text { on Likert scale, } 5 \text { - totally) }\end{array}$ & 16 & 32 \\
\hline Sol & urce: Adapted from Monge et al., (2013) & & \\
\hline
\end{tabular}

\section{Discussion}

Spear \& Bowen (1999), reports that many manufacturing companies around the world have tried unsuccessfully to imitate the success of the Toyota Production System (TPS), which is the cornerstone of lean manufacturing according to Womack et al., (1990), Spear and Bowen (1999) state that the cause of failure is that these companies believe that Toyota's success lies in the application of technical or manufacturing tools such as SMED, TPM , Kanban, etc. in an isolated way, which in their point of view is a wrong reasoning, success is directly related with the application disciplined and consistent of the 4 rules that constitutes the DNA of Toyota Production System such rules are: a) The form how people work - all activities must be perfectly well specified in content, sequence and timing, b) how people communicate - communication should be direct and unambiguous preferable yes or no, c) how the production line is built - the line must be as direct as possible and without stops in the flow of materials and products, d) how to improve people - all improvements must be executed at all organizational levels following strictly the scientific method. 
Liker et al., (2011) more recently established that more than $70 \%$ of implementations of lean manufacturing in the world fail, due to the lack of real and genuine commitment and leadership of senior management, as well as the lack of adequate employee education and training, which causes only be achieved "lean Silos" projects in the organizations, this statement essentially coincides with reports by Spear and Bowen, (1999) years ago.

In the case of Apodaca Mexico manufacturing plants, according to the results presented in this article, you can see similar plants behaviors to those mentioned by Spear and Bowen, (1999) and Liker et al., (2011). In other words a no outstanding performance is displayed in the field of lean manufacturing, but in that sense it must be said that large plants perform slightly better than medium plants.

Respecting sustainable manufacturing, according to the results obtained in this study on the aspects of this area, nor can see outstanding results in any of the categories of plants, this causes that companies are not getting the benefits that allows obtain the implementation of sustainable initiatives, including: development of new products and/or processes, penetrate new markets, improved public image, improved financial performance and competitive and strategic advantages, great brands reputation and increased generation shareholder value through the systematic elimination of environmental waste (Monge et al., 2014a 2014b, 2013; MIT \& BCG, 2013, 2011, 2009; EPA, 2000 Miller, 2011, Wills, 2009a, 2009b).

Finally in terms of continuous improvement, and as was already mentioned in the section on sustainable manufacturing, it is not present consistently and systematically in medium and large studied plants, according to the results shown in this study. In this sense is important to mention that because the lack of a systematic approach to continuous improvement that operates in a consistent and systematic way, with the active participation of the employees and the commitment and leadership of senior management (Liker et al., 2011), the plants will not be able to consolidate the lean manufacturing and sustainable manufacturing approaches, losing great benefits that are possible to obtain through a wide employee participation, abundant suggestions submission, high level of suggestions implemented, continuous improvement projects employee involvement in a great extent and a great daily time of the management dedicated to direct shop floor observation, these are according to Koenigsaecker, (2009) fundamental conditions for the success of an excellent continuous improvement system. The Apodaca plants show a far outstanding performance in the three approaches discussed in this article mainly continuous improvement.

\section{CONCLUSION}

According to the descriptive statistical analysis of the responses of plant managers within the sample of 40 manufacturing plants of Apodaca, México, effective implementation of lean manufacturing, sustainable manufacturing and continuous improvement is not observed, this indicates the low levels of adoption of practices that constitute each of those points, it is crucial therefore that plants redouble their efforts in order to take sustained and consistent practices of lean manufacturing, sustainable manufacturing and continuous improvement, in order to get in first instance the benefits that other manufacturing plants in other contexts are achieving, and also to stay on the cutting edge, gain competitive advantage and through them the viability in the medium and long term for the Apodaca plants. In this sense, the results obtained and shown in this study can be used as a guide to identify the weaker aspects of the plants analyzed in this article and related with lean manufacturing, sustainable manufacturing and continuous improvement, also doing deeper studies it would be possible to identify causes and barriers that have prevented the plants to adopt the referred approaches to be successful in them, define and structure specific improvement projects that take the plants to higher levels of performance in terms of: quality, cost, delivery times, safety, employee morale, innovation and environmental performance.

\section{Following studies}

It must be recognized the studied sample $(n=40)$ is a small sample only representative of Apodaca Mexico. This municipality is one of the most industrialized zone of México, but it not represents the total of manufacturing plants of México, so it is important to expand the study to others highly industrialized zones of the country and in this way to have a better picture of the level of adoption of lean manufacturing, sustainable manufacturing and continuous improvements approaches in others contexts. Also, it is important to develop a correlational/causal study to determine the factors and causes that impede the manufacturing Mexican plants the proper adoption of the initiatives studies in this article, and consequently to define the corrective actions in the adequate direction.

\section{REFERENCES}

Amin, M.A y Karim, M.A. (2013). A time-based quantitative approach for selecting lean strategies for manufacturing organisations, International Journal of Production Research, 51(4), ISSN: 00207543, 1146-1167.

Arrieta , J.G., Botero, V.E. y Romano, M.J. (2010). Benchmarking sobre la manufactura esbelta (lean manufacturing) en el sector de la confección en la ciudad de medellín, Colombia, Journal of Economics, Finance and Administrative Science (en línea), 15(28), ISSN: 2077-1886, 141-170.

Austin, D., Saleeshya, P.G. y Vamsi, N. (2013). A model to assess the lean capabilities of automotive industries, International Journal of Productivity and Quality Management, 11(2), ISSN: 1746-6482, 195.

Bergmiller, G.G. y Mc.Cright, P.R. (2011). Lean and sustainability programs: Evidence of operational synergy for lean manufacturers and logical growth toward sustainability, Review of Business Research, 11(5), ISSN: 1546-2609, 58-68.

Cardozo, E.R, Rodríguez, C. y Guaita, W. (2011). Las pequeñas y medianas empresas agroalimentarias en Venezuela y el desarrollo sustentable: Enfoque basado en los principios de la manufactura esbelta. Información Tecnológica (en línea), 22(5), ISSN: 0718-0764, 39-48.

Cooper, R. y Maskell, B. (2008), How to manage through worsebefore better, MIT Sloan Managemet Review, summer 2008, Vol. 49, No. 4, ISSN: $1532-9194$, pp. 58-65.

Cruz, J. \& Monge, C. (2015). Manufacturing excellence approach to business performance model, European Journal of Business and Economics, 10(1), ISSN: 1804-5839.

EPA. (2000). Pursuing perfection: Cases studies examining lean manufacturing strategies, pollution prevention and environmental regulatory management implications,1-22, EPA Environmental Protection Agency, USA, http: www.epa.gov, acceso: 10 de Julio (2011).

Ferdousi, Fy Ahmed. A. (2009). An investigation of Manufacturing Performance through Lean Production: A Study on Bangladeshi Garment Firms, International Journal of Business and Management, (4)/9, ISSN: 1833-8119, pp. 106-116

Ghosh, M. (2013). Lean Manufacturing performance in indian manufacturing plants, Journal of Manufacturing Technology Management, 24(1), ISSN: 1741038X, 113-122.

Imai, M. (1986). Kaizen: La Clave de la Ventaja Competitiva Japonesa, 1era. Ed, CECSA, DF México. 
Irastorza, V. y Fernández, X. (2010). Balance nacional de energía y su relación con el inventario nacional de emisiones (en línea) Revista Internacional de Estadística y Geografía México, 1(1) Noviembre, ISSN en trámite, 52-7, acceso: 10 de Marzo de (2013) http://rde.inegi.org.mx/revista_noviembre_2010/

Jiang, Z., Zhang, H y Sutherland, J.W. (2012). Development of an environmental performance assessment method for manufacturing process plans, International Journal of Advanced Manufacturing Technologies (on line), (58), ISSN: 1433-3015, 783-790.

Kidwell, M. (2006). Lean manufacturing and the environment Ignoring the 8th deadly waste leaves money on the table, Association for Manufacturing Excellence Target Magazine, 22(6), 13-18.

Koenigsaecker, G. (2009). Leading the Lean Enterprise Transformation, CRC Press, New York, 39-77.

KPMG México. (2009). Encuesta: Desarrollo sustentable en México (2009), KPMG Cárdenas Dosal, S.C., México DF, http://kpmg.com.mx, acceso: 5 de Noviembre de (2011), 4-27.

Lee, S. (2012). The impact of manufacturing practices on operational performance, Review of business research, 12(5), ISSN: 1546-2609, 184-189.

Liker, J y Convis, G. (2011). The toyota way to lean leadership, CRC Press, New York, pp. 1-10.

Millar, H.H y Rusell, S. (2011). The adoption of sustainable manufacturing practices in the Caribbean, Business Strategy and the Environment, 20, ISSN: 0964-4733, 512-526.

MIT y BCG. (2013). Findings from the 2012 sustainability and innovation global executive study and research report, MIT Sloan Management Review research report, winter, ISSN: 1532 9194, 1-13.

MIT y BCG. (2011). Sustainability: The "Embracers" seize the advantage, MIT Sloan Management Review Research Report winter, ISSN: 1532-9194, 5-22

MIT y BCG. (2009). The business of sustainability, MIT Sloan Management Review, Special Report, ISSN: 1532-9194, 3-14.

Monge, C. (2014a). Impacto de la manufactura esbelta, la manufactura sustentable y la mejora continua en la eficiencia operacional y responsabilidad ambiental de las plantas de manufactura de México, tesis doctoral Universidad Autónoma de Nuevo León, México.

Monge, C., Cruz, J \& López, F. (2014b). Manufacturing and continuous improvement areas using partial least squares path modeling with multiple regression comparison, Proceedings of CBU International Conference on Innovation, Technology Transfer and Education (2014), February 3-5, Prague, Czech Republic, 15-26.

Monge, C., Cruz, J. \& López, F. (2013). Impacto de la manufactura esbelta, manufactura sustentable y mejora continua en la eficiencia operacional y responsabilidad ambiental en México, Información Tecnológica, 24(4), ISSN: 07168756, pp. 15-31.

Murugesan, T.K., Kumar, B.S. y Kumar, M.S, (2012). Competitive advantage of world class manufacturing system (WCMS) - A study of manufacturing companies in south India, European Journal of Social Sciences, 29(2), ISSN: 1450-2267, 295-311.

Reyes-Aguilar, P. (2002). Manufactura delgada (lean) y seis sigma en empresas mexicanas: experiencia y reflexiones, Revista Contaduría Pública y Administración México, 205(Abril-Junio), ISSN 0186-1042, 51-67.

Rodríguez, I. (2011). Construya la eficiencia energética, Revista Manufactura Expansión México, Feb (2011), 41-45.

Schneider Study, (2011). Execs see energy as business, moral imperative, (en línea), EEUU, Plant Engineering, (2011), 1-2, acceso: 14 de Marzo (2011), http://www.plantengineering.com/singlearticle/schneider-study-execs-see-energy-as-business-moralimperative

Slaper, T.F. (2011). The triple bottom line: What is it and how does it work?, Journal of Indiana University Kelley School of business, spring (2011), ISSN: 0007-6813, 4-8.

Spear, S \& Bowen. (1999). Decoding the DNA of the Toyota production system, Harvard Business Review, sept-oct, ISSN: 00178012, pp. 95-106.

www.journals.cz
Toussaint. J.S. y Berry, L.L. (2013). The Promise of Lean in health care (on line), Mayo clinic proceedings, 88(1), ISSN: 1942-5546 $72-84$

Upadhye, N., Deshmukh, D.G. y Garg, S. (2010). Lean manufacturing for sustainable development, Global Business and Management Research, 2(1), ISSN: 1947-5657, 125-137.

Vinodh, S y Dino, J. (2012). Structural equation modeling of lean manufacturing practices, International Journal of Production Research, 50(6), ISSN: 00207543, 1598-1607.

Wills, B. (2009a). Green intentions; Creating a green value stream to compete and win, 3-34, CRC Press, New York, USA.

Wills, B. (2009b). The Business case for environmental sustainability (green); Achieving rapid returns from the practical integration of lean and green. HPS white paper, 1-6, acceso: 5 de Enero 2009, http://www.leanandgreensummit.com/LGBC.pdf

Womack, J.P, Jones, D.T y Roos, D. (1990). The machine that changed the world: The story of lean production systems 1st. Ed., Rawson Associates, 11-15, New York, USA, pp. 11-15. 